\title{
Farmers' Adoption of Soil and Water Conservation Practices: the Case of Lege-lafto Watershed, Dessie Zuria District, South Wollo, Ethiopia
}

\section{Gizachew Shewaye Yifru}

Wollo University

Birhan Asmame Miheretu ( $\nabla$ birhan1050@yahoo.com )

Wollo University

\section{Research}

Keywords: Adoption, Soil and water conservation, Erosion, Ethiopia

Posted Date: May 27th, 2021

DOl: https://doi.org/10.21203/rs.3.rs-522567/v1

License: (c) (1) This work is licensed under a Creative Commons Attribution 4.0 International License. Read Full License

Version of Record: A version of this preprint was published at PLOS ONE on April 11th, 2022. See the published version at https://doi.org/10.1371/journal.pone.0265071. 
Farmers' adoption of soil and water conservation practices: The case of LegeLafto Watershed, Dessie Zuria District, South Wollo, Ethiopia

\section{Gizachew Shewaye Yifru ${ }^{1}$ and Birhan Asmame Miheretu ${ }^{2}$}

${ }^{1}$ South Wollo Zone, Agriculture Department, Dessie, Ethiopia

${ }^{2}$ Department of Geography and Environmental Studies, Wollo University, Dessie, Ethiopia E-mail: birhan1050@yahoo.com

The corresponding author's contact information: Birhan Asmame Miheretu

Mobile phone: +251911568311

E-mail: birhan1050@yahoo.com

P.O.Box: 1145

Wollo University, Dessie, Ethiopia 


\title{
Farmers' adoption of soil and water conservation practices: The case of Lege- Lafto Watershed, Dessie Zuria District, South Wollo, Ethiopia
}

\begin{abstract}
This study was conducted to assess farmers' adoption decisions of soil and water conservation practices in Lege-Lafto Watershed, Dessie Zuria District, South Wollo, Ethiopia. Data were collected from 304 farmers using household survey, and through focus group discussions, key informant interviews, and field observation. Binary Logistic regression model and descriptive statistics were used to analyze the data. The results indicated that about $64 \%$ of the farmers adopted soil and water conservation practices in their plot of land. The findings depict soil bund, stone bund, stone-faced soil bund, loose stone and brush-wood check dams, hillside terrace and bund stabilized with vegetation are the types of soil and water conservation technologies which are practiced in the study area. The analysis result revealed adoption of soil and water conservation practices in the study area is significantly and positively influenced by the perception of farmers on erosion problem and SWC practices, family labour, education level, and membership in local institutions. However, distance from residence to the nearest market and farmland, off-farm activities, and the ratio of cultivable land to family size influenced the adoption of SWC practices negatively. Therefore, improving farmers' education status, strengthening local institutions, and empowering their members are vital for sustainable land management practices in the country.
\end{abstract}

\section{Keywords: Adoption, Soil and water conservation, Erosion, Ethiopia}

\section{Introduction}

Agriculture is the mainstay of Ethiopia's economy where its production is highly dependent on natural resources [4]. Agricultural land is a scarce resource in the Ethiopian highlands while it is the fundamental basis of rural livelihoods [3]. Due to drought and the growing decline in the quality and quantity of natural resources, which are the main basis of subsistence agriculture, the living conditions of the rural poor in the Ethiopian highlands have deteriorated [5]. Land degradation in rural Ethiopia is seen as one of the key factors for low productivity and food insecurity $[10,13,21]$. 
Soil degradation is one of the most serious environmental problems in Ethiopia particularly in the highlands $[10,20]$. In the Ethiopian highlands, significant deforestation of natural forests, high population pressure, unsustainable farming practices, and conversion of marginal land to agriculture and grazing land have resulted in soil degradation [11, 20,27]. The Ethiopian highlands have been experiencing declining soil fertility and severe soil erosion due to population pressure and the encroachment of the intensive farming system on steep and fragile lands $[4,14]$.

A national assessment of soil erosion in the 1980s found that roughly half of the land area of the highlands (roughly 27 million hectares) was moderately eroded; 14 million hectares were severely eroded. And the "point of no return" has crossed more than 2 million hectares of farmland in the sense that it was unlikely that economic crop production could be maintained in the future [19]. Plot-level soil loss assessment also shows the severity of the problem which indicated that average soil loss rates on croplands have been estimated at 42 tones $\mathrm{ha}^{-1} \mathrm{yr}^{-1}$ but may also reach up to 300 tone $\mathrm{ha}^{-1} \mathrm{yr}^{-1}$ in individual fields [20]. Such losses may lead to irreversible changes in soil productivity that have a direct effect on Ethiopia's food security situation, with farmers unable to tolerate further deterioration in soil productivity [29] and as a result of this, agricultural production in the Northern highlands of Ethiopia is low [7]. Thus, Ethiopia's highland agricultural system is deterioration resulting from soil erosion and nutrient depletion [15].

To mitigate the depletion of soil and its long-term impact on its productivity, it needs to be managed by appropriate soil and water conservation measures [25]. Soil conservation is critically required in these areas [14]. Based on this reality, the government of Ethiopia and nongovernmental organizations have invested much in soil and water conservation practices since the mid-1970s to reduce soil erosion, to improve agricultural productivity and food security $[6,30,34]$. The largest soil and water conservation activities were implemented during the 1970s and 1980s by mobilizing farmers mainly through food and work programs, though the result of the effort is minimal as the practices were not adopted by farmers $[9,23,30]$. In between the years 1995 and 2009, soil and water conservation practice was considered as a part of the agricultural extension package therefore implemented through the classical top-down approach. Moreover, the government of Ethiopia instituted a national physical SWC construction campaign since 2011 that runs for two months (January and February) every year in the high potential as 
well as low potential areas. The campaign is aimed at mobilizing the community to construct the necessary structures following watershed conservation principles. This approach is intended to change the attitudes of the farmers and ensure that the SWC structures are sustainable and effective [6]. Notwithstanding substantial efforts to establish and encourage different types of soil and water conservation practices, land users have not been generally adopted and used on a sustained basis for various reasons [4, 11, 12, 23, 30. 35 ]. The problem might be explained by the fact that the adoption of soil and water conservation practices is influenced by demographic, socioeconomic, institutional, and biophysical factors that are unique and complex in the area[4, 12, 36 These studies on the decision to invest in soil and water conservation practices are not complete. For instance, [4] used the stone terrace to determine the farmers' adoption of soil and water conservation practices. But, considering a single conservation technology to determine the adoption of soil and water conservation practices is not complete as every conservation technology is not applied everywhere [18, 25]. This indicates that our knowledge of the adoption

of soil and water conservation (SWC) measures is not complete and information available is fragmented in coverage and does not provide a full picture of the diverse topography, relief features, and eco environments of the country. Furthermore, there was no adoption of SWC measures study in the study area, and it has been frequently hit by erosion hazards. Cognizant of this, the study identifies the determinant factors influencing farmers' adoption decisions of soil and water conservation practices in Lege-Lafto Watershed, Dessie Zuria District, South Wollo, Ethiopia. Thus, scientific analysis of SWC measures is paramount importance to adopt SWC practices and would help for designing area-specific land management strategies.

\section{Materials and Methods}

\section{Description of the study area}

This study was conducted at Lege lafto watershed of Dissie Zuria district which is located in South Wollo zone, Ethiopia. The watershed is located $37 \mathrm{~km}$ far from Dessie town to southwest, and about $438 \mathrm{~km}$ northeast of Addis Ababa. Geographically, it lies between 1056' $0^{\prime \prime}$ to $11^{\circ} 9^{\prime}$ 0" N Latitude and $39^{\circ} 25^{\prime} 20^{\prime}$ ' to $39^{0} 33^{\prime \prime} 20^{\prime}$ E Longitude (Fig.1). It is part of the headstreams of the Abay basin located on edge of the western escarpment of the rift valley and in the NorthEastern parts of central high lands of Ethiopia. The total area of the watershed is 24286 hectares. The slope of the watershed is flat to almost flat (1.0\%), 5.6\% is gently sloping, $13.6 \%$ is sloping, 
$33.0 \%$ is moderately steep sloping, $26.2 \%$ is steeply sloping and $20.6 \%$ is extremely steep sloping. The steep slope and rugged terrain of the watershed are natural hazards for soil erosion and such physiographic conditions, even rains of moderate-intensity are enough to cause massive erosion. The mean annual rainfall of the area is $1365.7 \mathrm{~mm}$ with a maximum of $2074.4 \mathrm{~mm}$ in 2018 and a minimum of $902.4 \mathrm{~mm}$ in 2007 . The mean annual temperature of the study area is $9^{\circ} \mathrm{c}$. The warmest month is June $\left(10.4^{\circ} \mathrm{c}\right)$ while the coldest month is January $\left(7.4^{\circ} \mathrm{c}\right)$.

Fig.1 Location map of Lege-lafto watershed, Dessie Zuria District, South Wollo, Ethiopia

The type of farming system is mixed cereal-livestock. Barley (Hordeum vulgare) is the common type of crop in upper part, while wheat (Triticum vulgare), teff (Eragrostic teff), maize (Zea mays) and sorghum (Sorghum bicolor) become widespread down to the lower. Legumes such as horse beans (Vicia faba), field peas (Pisume sativum), chick peas (Cisor arietianum) and lentils (Lens culinaries) could be produced. Few farmers also engaged in producing potato (Solanum tuberosum), gomen (Brassica carinata), and onion (Allium cepa) from irrigated land. Livestock is intimately incorporated into the farming system. It supports crop production mainly as draught power in addition to the source of milk, meat, and cash income. Farmers generate income from off-farm activities. Selling of fire/pole woods, petty trade, and labor hire -out are source income for farmers.

\section{Methodology}

A concurrent mixed research design was employed in this study as qualitative and quantitative research methods were used side-by-side assuming both methods have equal importance.

\section{Sampling technique and Selection procedure}

Both purposive and systematic random sampling techniques were used to select study area and sample households, respectively. First, Dessie Zuria district was purposely selected based on the discussion held with south wollo zone natural resource experts as this district is realized by its soil erosion induced degradation, topographic variation, and long history in conservation effort. In the second stage, the study watershed was selected in the same manner based on the discussion held with Dessie zuria district natural resource experts. In the third stage, three kebeles were selected from the upper, middle, and lower sections of the watershed to represent 
the entire area. Tebasite, Gelisha, and Asgedo kebeles were selected from the upper, middle, and lower sections of the watershed, respectively.

Households of selected kebeles are considered as the survey population and the number of sample households was decided by using [33] formula. From the total 3251 farm household heads of kebeles, 357 respondents was selected by using systematic random sampling technique. Finally, proportional numbers of sample respondents were used from each kebeles. Sampling was undertaken from lists obtained in development agent offices. Fifty-three questionnaires were dropped out from analysis because of incompleteness and inconsistent response. Hence, only 304 questionnaires were used for the analysis.

\section{Data source and data collection techniques}

Questionnaires, in-depth interview, focus group discussion, and field observation was used as the main primary data collection techniques. The questionnaire included both closed and open-ended questions. The questionnaire enabled to collect data from representative sample household farmers. A structured questionnaire was designed for the interview also pretested with ten (10) respondents before the actual survey. The designed questionnaire covered a wide range of questions, which were intended to assess the adoption of soil and water conservation practices in the study area

To supplement the information obtained from the household questionnaires, Focus group discussion (FGD), key informant interviews, and field observation were conducted in the study area. The researchers used these tools to systematically generate information on the adoption of soil and water conservation practices they had observed and existing SWC measures. A total of three FGDs, one from each of the upper, middle, and lower watershed, were conducted. Eight discussants including local elders, local opinion makers, and agricultural extension workers participated in each of the FGDs. These were individuals who have access to information on SWC measures and were stayed in the study area for more than 25 years. A focus group checklist was administered in the local language. This checklist, comprised of open-ended questions around a set of SWC measures, was used to structure the discussions of participants' perspectives on how they implement different SWC measures in their plot of land, and how this reduces soil erosion. Detailed notes were taken throughout the discussions. Besides, a total of 15 individual interviews with local community members were held to collect additional information 
and understand how their surroundings evolved overtime and learn more from their observations on SWC practices in the study area. The researchers had chosen these key informants considering that they have adequate knowledge about the area and be able to memorize well its historical SWC practices. Field observations focusing on biophysical features, erosion indicators, farming practices, and conservation practices was carried out. Inaddition, secondary data were gathered from the department of Agriculture, books, and journals.

\section{Methods of Data analysis}

Data gathered from sample households' were analyzed using descriptive statistics and binary logistic regression model. Qualitative data gathered using focus group discussions, field observation, and key informant interviews were analyzed qualitatively by simple narrations.

Farmers' perceptions of erosion and soil and water conservation (SWC) practices are analyzed by descriptive statistics.. The result of the analysis is presented as frequency counts and percentage tables. T-test is used to compare the mean difference between adopter and nonadopter of the practices. Furthermore, the chi-square test is used to check if there is an association between categorical variables and the adoption of soil and water conservation practices.

\section{Binary Logistic Regression model}

The logistic regression model is used to explore farmers' perception, demographic, economic, institutional, and physical factors influencing the adoption of soil and water conservation practices. A logistic regression model is an appropriate statistical tool when the dependent variable contains two groups (dichotomous) and the explanatory variables are continuous and categorical [32]. (Wuensch 2014). In the logistic model, the coefficients are compared with the probability of an event occurring or not occurring and bounded between 0 and 1 . The dependent variable becomes the natural logarithm of odds when a positive choice is made. The result of binary helped to investigate the degree and direction of the relationship between the dependent and independent variables in the adoption of the practices at household level. If the estimated values of the variables are positive and significant, farmers with higher values for the variables are more likely to adopt the soil and water conservation practices.

The model is specified as (Agresti 1996):

$\operatorname{Ln}(\mathrm{PX} / 1-\mathrm{Px})=\beta_{0}+\beta_{1} \mathrm{X}_{1 \mathrm{i}}+\beta_{2} \mathrm{X}_{2 \mathrm{i}}+\cdots \beta_{\mathrm{k}} \mathrm{X}_{\mathrm{ki}}$ 
Where, the subscript $i$ is the $i^{\text {th }}$ observation in the sample, $P_{x}$ is the probability of an event occurring for an observed set of variables $\mathrm{X}_{\mathrm{i}}$ i.e. the probability that farmer adopts the practices and (1-Px) is the probability of non-adoption. $\beta_{0}$ is the intercept term and $\beta_{1}, \beta_{2} \ldots \ldots \ldots \beta_{k}$, are the coefficients of the explanatory variables $\mathrm{X}_{1}, \mathrm{X}_{2} \ldots \ldots \ldots \mathrm{X}_{\mathrm{k}}$.

Therefore, the above model is used in this part to identify factors influencing the adoption of soil and water conservation practices in the study area. Before running the regression model multicollinearity among the explanatory variables is checked.

\section{Definition of variables and working hypothesis}

\section{Dependent variable}

Introduced soil and water conservation technologies to the area include soil, stone and stonefaced soil bunds, loose stone and brushwood check dams, hillside terrace, and stabilized bund with multi-purpose species. A Farmer that constructs and maintains at least one of the introduced soil and water conservation (SWC) technology either as recommended or with some modification is defined as the adopters. Therefore, a value of " 1 " is assigned to all households that constructed and maintained the technologies on his/her farmland (the "adopters") and " 0 ", is assigned to households who used indigenous and/or not- maintained the introduced technologies (the "non-adopters").

\section{Selection of explanatory variables and expected impact on Adoption}

The adoption of soil and water conservation practices in the study area is a complex process that could be influenced by attitudinal, social, economical, institutional, and physical factors (Table $1)$.

Table 1 Definition of explanatory variables used in the model

The quantitative data was first entered into computer-based Statistical Package for Social Sciences (SPSS) software (version20) and the statistical analysis was done using this software. 


\section{Results and discussions}

Types of soil and water conservation practices that were implemented in the study area Most of the surveyed farmers $(86.5 \%)$ believe that soil erosion could be controlled. In line with this result, previous studies $[22,30,31]$. reported that the majority of their surveyed farmers confirmed erosion could be controlled. During the focus group discussion and key informant interview farmers were identified the types of soil and water conservation measures that are implementing in their plot of land. These are traditional and/ or modern soil and water conservation (SWC) practices. The traditional soil and water conservation practices such as cultivating along the contour and traditional ditch have been used by farmers. Contour ploughing is used independently or in combination with other conservation practices such as stone and soil bunds. It has been carried out by using the ox-drawn plough hence, it is considered as an element of normal farming practices, also, the practice needs no extra labor and time for construction and maintenance like to terraces. Traditional ditch is used for removing excess water from cultivated plots to waterways in a non-erosive way and was implemented except on extremely sloping plots in every cropping season. Hence, it is considered as a production practice designed to minimize the waterlogging problem rather than a conservation practice.

Improved soil and water conservation (SWC) practices were introduced to the study area since the mid-1970s. The introduced soil and water conservation practices have been implemented by the farmers. Implemented conservation technologies were mostly physical conservation technologies. These technologies include loose stone check dam, soil bund (Fig. 2), stone bund (Fig. 3), stone-faced-soil bund (Fig. 4), hillside terrace (Fig. 5), and brush-wood check-dam (Fig. 6). Biological soil and water conservation measures like bund stabilization using grasses and/or legume shrubs are also implemented by farmers (Fig.7).

Fig. 2 Up-graded soil bund in study area

Fig. 7: Stabilized bund with Desho grass

Fig. 5 Hillside terraces
Fig. 3 Stone bund in study area

Fig. 4 Stone -faced soil bund 
The study showed that 64.5 percent of the farmers were constructed and maintained soil and water conservation technologies. As indicated in Fig.8, 23.5, 35.2, 27.6, 6.6, 5.1, 1.5 and 0.5 percent of the farmers, respectively adopted soil bund, stone bund, stone faced soil bund, loose stone check dam, bund stabilization using grasses and/or legume shrubs, hillside terraces and brushwood check-dams in the study area.

Fig. 8 Soil and water conservation practices in Lege-lafto watershed

\section{Farmers' perception of soil and water conservation practices in the study area}

Farmers' perception of soil and water conservation practices significantly contributes for the adoption of the practices. They perceived that soil and water conservation (SWC) practices can be improving agricultural production (97.7\%), soil loss reduction (91.8\%), controlling flood (96.7\%), improving soil fertility (88.5\%), creating better farming plot (61.8\%) and becoming the source of fuelwood and forage (77.0\%). This is in line with [22] who reported that $93.5 \%$ of farmers perceived the positive role of the practices for reducing soil erosion problems.

During the group discussion and key informant interview held with farmers, the effectiveness of soil and water conservation practices was emphasized as they observed better growth and development of crops mainly along conservation technologies where fertile sediments were trapped. They also evaluated the amount of sediment trapped by soil and water conservation practices were very high which would be taken away out of the field if those conservation technologies were not constructed. Moreover, the majority of the farmers (93.4\%) expressed their interest to use the soil and water conservation (SWC) practices in their plot of land in the study area. However, the major constraint cited by farmers to construct and maintain soil and water conservation (SWC) practices in the study area was the technologies requiring much labor. Similarly, studies by [8, 30] reported that 92 and 88 percent of farmers were respectively, constrained by the technology being labor-intensive for construction.

\section{Adoption status of soil and water conservation practices in the study area}

Adopters and non-adopters significantly were different in eight of the nine hypothesized continuous variables (Table 2). The age of adopters and non- adopters was about 45 and 46 years, respectively. The mean walking distance measured in minutes between farmers' homesteads and the nearest market was 52.4 and 58.6 minutes for adopter and non-adopters, 
respectively. It showed that adopters had lower walking distance than non-adopters and the difference between the two groups (adopters and non-adopters) is statistically significant. This implies the adoption of soil and water conservation (SWC) practices is enhanced as the walking distance of farmers' residence and nearest market decrease.

In terms of household size, adopters were shown to contain slightly more household size than non -adopters. The results revealed that adopters, on average, had 4.86 persons compared to the 4.52 persons of non-adopters and the difference among them was statistically significant. This showed that the adoption of SWC practices is increased as the size of a household increased. Adopters had slightly more farmland size than non -adopters. Statistics showed that adopters, on average, had 0.86 compared to 0.78 of non-adopters and the difference among the groups was also statistically significant. This implies as the size of farmland increases adoption of soil and water (SWC) practices is also increases in the study area. The results also showed that adopters had a 0.14 land-to- man ratio while non- adopters had 0.15 and the difference among groups (adopter and non-adopter) was statistically significant. This verifies as the ratio of land-to-man ratio decreases the adoption of SWC practices is increased in the study area.

Moreover, as indicated in Table 2 adopters, on average, had 3.37 TLU compared to 3.10 of nonadopters and the difference was also statistically significant. This indicates as the farmer holds more livestock the adoption of SWC practices is enhanced in the study area. The difference between adopters and nonadopters was statistically significant in the study area. This result suggests that as the distance between farmers' residence and farmlands increased adoption of soil and water conservation practices become less or vice versa. The dependency ratio was found to differ significantly between adopters and non-adopters. The results showed that as the number of dependent family members in a household increased, adoption SWC practices become less or vice versa in the study area. In addition, the findings indicated that as the number of working-age members in a household increases, the adoption of SWC practices could be enhanced in the study area.

Table 2 Continuous variables differing adopters from non-adopters of SWC technologies in legelafto watershed

The results of the study indicated that $86.2 \%$ of the adopter and $74.1 \%$ of non- adopter perceive the problem of soil erosion in their plot of land. The chi-square test showed that perceiving the problem of soil erosion is significantly connected with the adoption of soil and water 
conservation (SWC) practices. This indicates the adoption of SWC practices is increased when farmers perceived the problem of soil erosion on their farmland. The adoption of soil and water conservation practices is determined by their perception of soil and water conservation (SWC) practices. The chi-square test revealed that the perception of SWC practices is significantly associated with the adoption of the practices. This pointed out that the adoption of soil and water conservation (SWC) practices is enhanced when farmers perceived the effectiveness of conservation practices. The findings also showed that non-adopters were more employed in offfarm activities (67.6\%) than adopters (44.4\%). This implies as farmers employed in off-farm activities the adoption of soil and water conservation (SWC) practices become less in the study area

Table 3 Categorical variables distinguishing adopters from non-adopters of SWC practices in Lege-lafto watershed

Development agents provide agricultural extension services including training on soil and water conservation practices for farmers. Both extension service and training on conservation practices enhanced the adoption of SWC practice in the study area. Regarding the source of farmland, $88.3 \%$ of adopters and $76.9 \%$ of non- adopters possess their farmland. The result of the chisquare test disclosed that land ownership is significantly associated with the adoption of SWC practices in the study area. This designated that farmers adopt soil and water conservation (SWC) practices on their plot of land than other sources. The results of the chi-square test in Table 3 also showed that perceiving farmland as sloppy, membership in the local institution, and credit access are significantly associated with the adoption of soil and water conservation (SWC) practices in the study.

\section{Determinants for the adoption of SWC measures in the study area}

The logistic regression model was used to identify the factors that influenced the adoption behaviors of farmers on soil and water conservation practices in the study area. Before running the logistic regression analysis, the existence of multi-collinearity among the explanatory variables was checked. The result of collinearity statistics showed that there is no variable that resulted in a tolerance value of less than 0.1 . Moreover, the result of the variance inflation factor 
(VIF) is very small (much less than 10). Consequently, all variables are included for the final analysis as there is no multi-collinearity problem.

The estimated binary logistic regression model coefficients, Wald test, standard error, and significance levels are presented in Table 4. Regarding the performance of the model, the likelihood ratio test statistic exceeds the chi-square critical value (169.514) with 22 degrees of freedom. The result was highly significant $(\mathrm{P}=0.00)$ suggesting well fitness of the model. Similarly, the output of the Hosmer and Lemeshow (H-L) goodness-of-fit test indicated a nonsignificant probability ( $\mathrm{p}=0.102)$ value signifying the good fitness of the model. The comparison among the correctly predicted observations with the constants included in the model also indicated that $82.9 \%$ of the observations were correctly predicted at 0.5 cut value. Correctly predicted adopters and non-adopters of the model are $90.8 \%$ and $68.5 \%$, respectively. The pseudo $\mathrm{R}^{2}$ was 0.587 also indicating the predictor variables in the model explained about $58.7 \%$ of the variation in the adoption of soil and water conservation practices in the study area. The results of the binary logistic regression model analysis revealed that the adoption of soil and water conservation practices in the study area is influenced by several factors. The factors that positively and significantly influencing the adoption of soil and water conservation practice were perception on soil and water conservation practice and soil erosion problem, education level and a member of a local institution, family labour while engagement in off-farm activities, walking distance between farmland and residence, the distance between nearest market and home and land- to- man ratio were found to be negatively and significantly influencing the adoption of SWC practices in the study area (Table 4).

Table 4 Binary Logistic Regression Model estimates for the adoption of SWC practices in Legelafto watershed

The study results indicated that farmers' perception of soil and water conservation (SWC) practice affects their adoption positively and significantly in the study area. The adoption of SWC practices increases with the perception of farmers about the positive role of SWC practices to mitigate soil erosion. This shows that perception of the effectiveness of SWC practices is a necessary condition to adopt the practices. This result is in line with the findings of $[4,10]$. who reported that farmers' perception of technology attributes influenced positively and significantly their adoption decision on conservation practices. 
The result of binary logistic regression analysis depicted that the perception of soil erosion as a problem affects the use of SWC practices positively and significantly. This indicates that farmers who perceived the problem better are expected to invest more in conservation practices. Similary, Sileshi et al. (2019) indicated that farmers who had already perceived their plots to have soil erosion problems were more likely to adopt SWC measures than those who did not. The educational level of farmers increases their ability to get and use the information and improves farmers' decision to adopt SWC practices. The farmers' education status affects their use of soil and water conservation practices positively and significantly among the farmers of Lege- lafto watershed. This finding corroborates with the finding of previous studies $[1,10,16$, 26] who stated that better education level of household heads having a strong and positive relationship with farmers' adoption of SWC conservation practices.

Being membership in a local organization (Development groups and watershed user association) assists a person to obtain information on improved farming practices. This factor is positively and significantly influenced by the use of soil and water conservation (SWC) practices in the study area. This means local organizations have an immense contribution to the adoption of conservation practices.

The results showed that involvement in off-farm activities was negatively and significantly influencing the adoption of SWC practices in the study area. This implies that there is labor competition between off-farm activities and SWC practices that discourage farmers from engaging in the implementation and maintenance of conservation practices on their plot of lands. This result is in line with the findings of other empirical studies $[4,10,16,28]$.

The distance of farmland from homestead negatively and significantly influenced farmers' adoption decisions in the study area. This implies that a unit increase in walking distance between farmland and residential area lowers significantly the use of conservation practices. Farmers want to invest more on the nearest farmlands as far away farmlands discouraged them to construct and maintain soil and water conservation practices. This result is in line with the previous studies $[12,16,17,26]$ who reported that the longer the walking distance between farmland and residential area, the less in the adoption of soil and water conservation practices.

In seriously degraded and scarce farmland, vulnerability to starvation increases by decreasing land -to- man ratio. Therefore, it is assumed that the adoption of soil and water conservation practices increased with a decrease in cultivatable land- to -man ratio (LNDRTIO). The findings 
showed that a unit increase in the land -to- man ratio lower significantly the use of SWC technologies there-by providing more evidence for supporting the Boserupian hypothesis that is population pressure induces households to intensify their farming practices there-by adopting farmland improving practices.

The results indicated that market distance was negatively and significantly affects the adoption of SWC practices. This implies that a unit increases in walking distance between market and residential areas lower significantly the adoption of soil and water conservation (SWC) practices. This is consistent with the earlier study by [13].

Families are an important source of labour for farm operations and the construction of SWC practices. The findings showed that the family size (FMLABOUR) was positively and significantly affects the adoption of SWC practices in the study area. A unit increases in the number of working-age members increase significantly the use of SWCpractices. This suggests that households that are endowed with much working-age family labor favor the adoption of SWC practices. This is in line with the findings of previous studies by [13, 24].

\section{Conclusions}

The result of the study revealed that farmers perceive soil erosion as a problem and they believed that erosion could be controlled by adopting SWC practices. Different types of SWC practices were introduced to the study area. Adopted soil and water conservation (SWC) practices are soil bund, stone bund, stone-faced soil bund, loose stone check dam, brush wood check dam and hillside terrace, and bund stabilization with legumes and grass.

The results of the binary logistic regression model analysis revealed that the factors that positively and significantly influencing the adoption of soil and water conservation practice were perception on soil and water conservation practice and soil erosion problem, education level and a member of a local institution, family labour while engagement in off-farm activities, walking distance between farmland and residence, the distance between nearest market and home and land- to- man ratio were found to be negatively and significantly influencing the adoption of SWC practices in the study area. Therefore, to increase the likelihood of adoption, agricultural practitioners should organize and train farmers to effectively introduce conservation initiatives. Based on these results, we also suggest that efforts to resolve land degradation using SWC mechanisms should concentrate on human and institutional capacity building of farmers. 


\section{Declarations:}

\section{Acknowledgments}

This research was financially supported by South Wollo Agriculture office and the researchers are greatly indebted for that. Thanks to the interviewees and the farmers of the study area in contributing their share for the fruitfulness of this research. We are also grateful to agricultural experts at Dessie Zuria district for sharing their ideas and technical supports.

\section{Authors' contributions}

The corresponding author BA Miheretu critically revises the manuscript. He has also contributed in sampling design, reviewing and writing the draft manuscript. The first author GS Yifru has made substantial contributions in the design, data collection, data entry, data analysis and interpretation of results. Both authors have read and approved the final manuscript.

\section{Funding}

This work was supported by South Wollo Agriculture office, Dessie, Ethiopia.

\section{Availability of data and materials}

All data analyzed during this study are available from the corresponding author, upon reasonable request.

\section{Competing interests}

The authors declare that they have no competing interests.

\section{References}

1. Agere B, Wuletaw M, Nachimuthu K (2020) Factors influencing adoption of soil and water conservation practices in the northwest Ethiopian highlands. Intern Soil and Water Cons Res 8: $80-89$

2. Agresti A (1996) An introduction to Categorical data analysis. Wiley,USA

3. Akalu T, De Graaff J, Ritsema C, Menale K (2014) Farmers' perceptions about the influence of land quality, land fragmentation and tenure systems on sustainable land management in the north western Ethiopian highlands. Lan Deg Dev. DOI: 10.1002/ldr.2298

4. Aklilu A, De Graaff J (2007) Determinants of adoption and continued use of stone terraces for soil and water conservation in an Ethiopian highland watershed. Eco econ 61: 294-302 
5. Anley Y, Bogale A, Haile-Gabriel A (2007) Adoption Decision and Use Intensity of Soil and Water Conservation Measures by Smallholder Subsistence Farmers in Dedo District, Western Ethiopia. Lan Deg Dev 18: 289-302

6. Asnake M, Heinimann A, Gete Z, Hurni H (2018) Factors influencing the adoption of physical soil and water conservation practices in the Ethiopian highlands. Intern Soil and Water Cons Res 6:23-30

7. Assefa A, Van Keulen H (2009) Modelling soil nutrient dynamics under lternative farm management practices in the Northern Highlands of Ethiopia. Soil \& Tillage Res 103: 203215.

8. Assefa D, Steenhuis TS, Blake RW, Selamyihun K, Collick AS, Dadgari F (2010) Assessment of soil erosion processes and farmer perception of land conservation in Debre Mewi watershed near Lake Tana, Ethiopia. Ecohyd and Hydrobio 10:297-306. https://doi.org/10.2478/v10104-011-0013-8.

9. Azene B (1997) A Participatory Agro-forestry Approach for Soil and Water Conservation In Ethiopia. Tropical Resource Management Paper No. 17, Wageningen Agricultural University: Wageningen.

10. Bekele S, Holden S (1998) Resource Degradation and Adoption of Land Conservation Technologies in the Ethiopian Highlands: A Case Study in Andit Tid, North Shewa. Agri Econ 18: 233-247

11. Bekele S, Holden S (1999) Soil Erosion and Smallholder's Conservation Decisions in the Highlands of Ethiopia. World Devt 27: 739-752

12. Bekele W, Drake L (2003) Soil and Water Conservation Decision Behavior of Subsistence Farmers in the Eastern Highlands of Ethiopia: A Case Study of the Hunde-Lafto Area. Ecol Econ, 46: 437-451.http://dx.doi.org/10.1016/S0921-8009(03)00166-6.

13. Berhanu G, Swinton SM (2003) Investment in soil conservation in northern Ethiopia: the role of land tenure security and public programs. Agri Econ 29:69-84

14. Bewket W, Teferi, E (2009) Assessment of soil erosion hazard and prioritization for treatment at the watershed level: case study in the Chemoga watershed, Blue Nile basin, Ethiopia. Lan Deg Dev 20: 609-622 
15. Birhan A, Assefa A (2017) Determinants of farmers' adoption of land management practices in Gelana sub-watershed of Northern highlands of Ethiopia. Ecol Process 6:19. https://doi.org/10.1186/s13717-017-0085-5.

16. Daniel A, Mulugeta N (2017) Factors affecting adoption of soil and Water Conservation practices: The case Of Wereillu Woreda (District), South Wollo Zone, Amhara Region, Ethiopia. Intern Soil and Water Cons Res 5: 273-279

17. Desalew M, Aklilu A. (2017) Determinants of farmers' perception to Invest in Soil and water conservation technologies in the North-Western Highlands of Ethiopia. Intern Soil and Water Cons Res 5: 56-61

18. Ervin C, Ervin D (1982) Factors affecting the Use of Soil Conservation Practices: Hypotheses, Evidence and Policy Implications.” Land Econ 58: 277-291

19. FAO (1986) Ethiopian Highlands Reclamation Study. Final report,Vol. 1 . Rome.

20. Hurni H (1993) Land degradation, famine, and resource scenario in Ethiopia. In Pimentel (ed). world Soil erosion And conservation, Cambridge studies In applied ecology and Resource Management 27-61

21. Kassie M, Zikhali P, Pender J, Kohlin G (2010) The economics of sustainable land management practices in the Ethiopian highlands. J Agri Econ 61:605-627

22. Melku D., Asfaw K, Awdenegest M (2019) Farmers' Perception of Soil Erosion and Adoption of Soil Conservation Technologies at Geshy Sub-Catchment, Gojeb River Catchment, Ethiopia. Agril Sciences 10:46-65

23. Menale K, Zikhali P, Kebede M, Edwards S (2009) Adoption of sustainable agriculture practices: Evidence from a semi-arid region of Ethiopia. Nat Resou Forum 33:189-198.

24. Million T, Kassa B (2004) Factors influencing adoption of Soil Conservation measures in Southern Ethiopia: The case of Gununo Area. J Agri and Rural Deve in the Tropics and SubTropics 105: 49-62

25. Morgan RPC (2005) Soil Erosion and Soil Conservation 3rd ed: Blackwell Publishing Company. UK.

26. Muluken GW, Okoyo EN, Erkalo E (2020) Factors influencing adoption of improved structural soil and water conservation measures in Eastern Ethiopia. Environ Syst Res 9:13. https://doi.org/10.1186/s40068-020-00175-4 
27. Shimeles D, Lulseged T, Vlek PL ( 2013) Performance of exclosure in restoring soil fertility: A case of Gubalafto district in North Wello Zone, northern highlands of Ethiopia. Catena 101:136-142

28. Sileshi M, Kadigi R, Mutabazi K, Sieber S (2019) Determinants for adoption of physical soil and water conservation measures by smallholder farmers in Ethiopia. Intern Soil and Water Cons Res 7 : 354-361

29. Sonneveld B.G, Keyzer MA (2003) Land under pressure: soil conservation concerns and opportunities for Ethiopia. Lan Deg Dev 14: 5-23

30. Woldeamlak B (2007) Soil and water conservation intervention with conventional technologies in north-western highlands of Ethiopia: acceptance and adoption by farmers. Land Use Policy 24: 404-416

31. Woldeamlak B, Sterk G (2002) Farmers' participation in soil and water Conservation Activities in Ethiopia in The chemoga watershed, Blue Nile Basin, Ethiopia, Lan Deg Dev13: 189-200

32. Wuensch KL (2014) Binary Logistic Regression with SPSS.

33. Yamane T (1967) Statistics: An Introductory Analysis, 2nd Edition, New York: Harper and Row.

34. Yohannes G (1999) The use, maintenance and development of soil and water conservation measures by small-scale farming households in different agro-climatic zones of Northern Showa and Southern Wello, Ethiopa. PhD Thesis, University of Bern,Switzerland

35. Zenebe A, Kessler A (2012) Farmers' investments in land management practices in the Central Rift Valley of Ethiopia. In Paper presented to the "8th International Symposium Agro Environ 2012". Wageningen, the Netherlands.

36. Zenenebe A, Kessler A, Hengsdijk H (2012) Exploring determinants of farmers' investments in land management in the Central Rift Valley of Ethiopia. App Geo 35: 191-198 


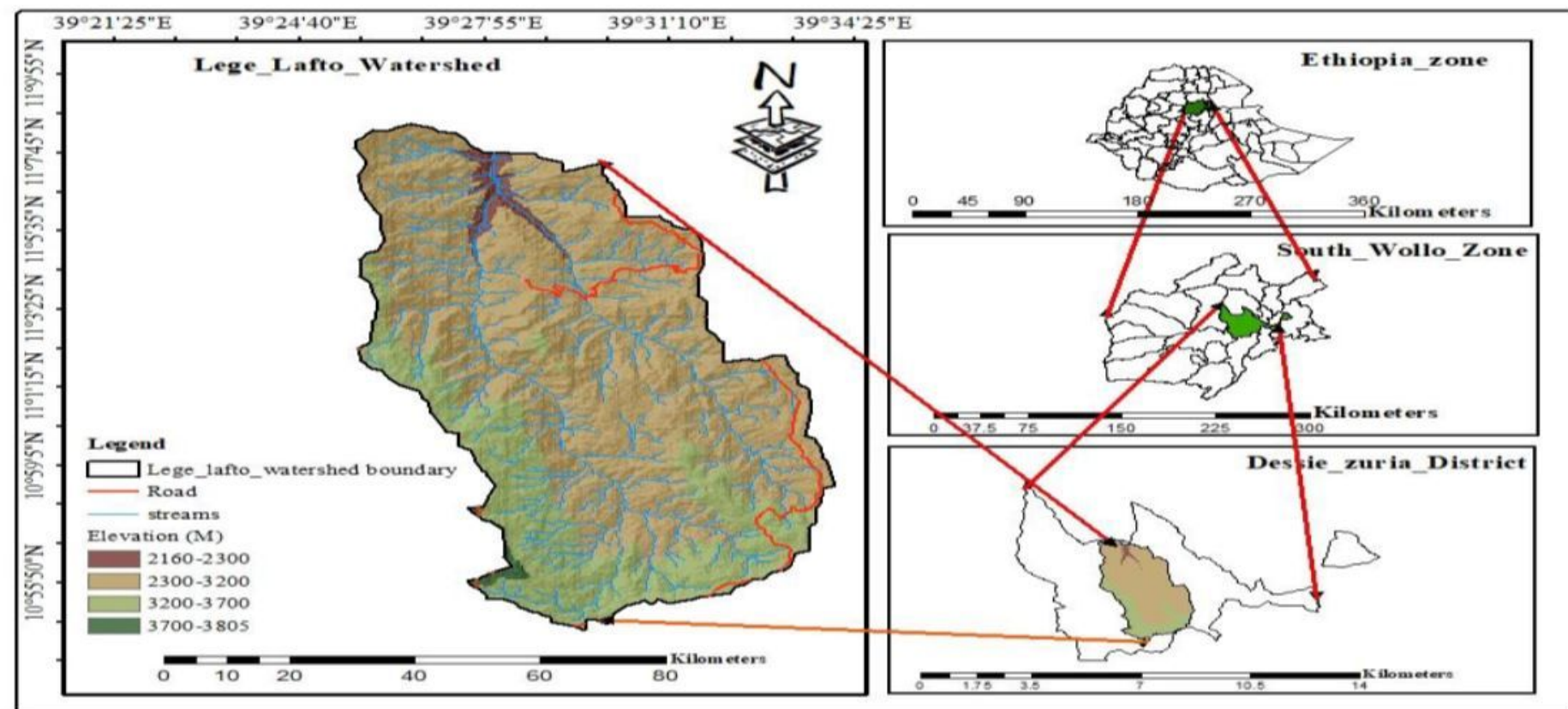

Figure 1

Location map of Lege-lafto watershed, Dessie Zuria District, South Wollo, Ethiopia Note: The designations employed and the presentation of the material on this map do not imply the expression of any opinion whatsoever on the part of Research Square concerning the legal status of any country, territory, city or area or of its authorities, or concerning the delimitation of its frontiers or boundaries. This map has been provided by the authors. 


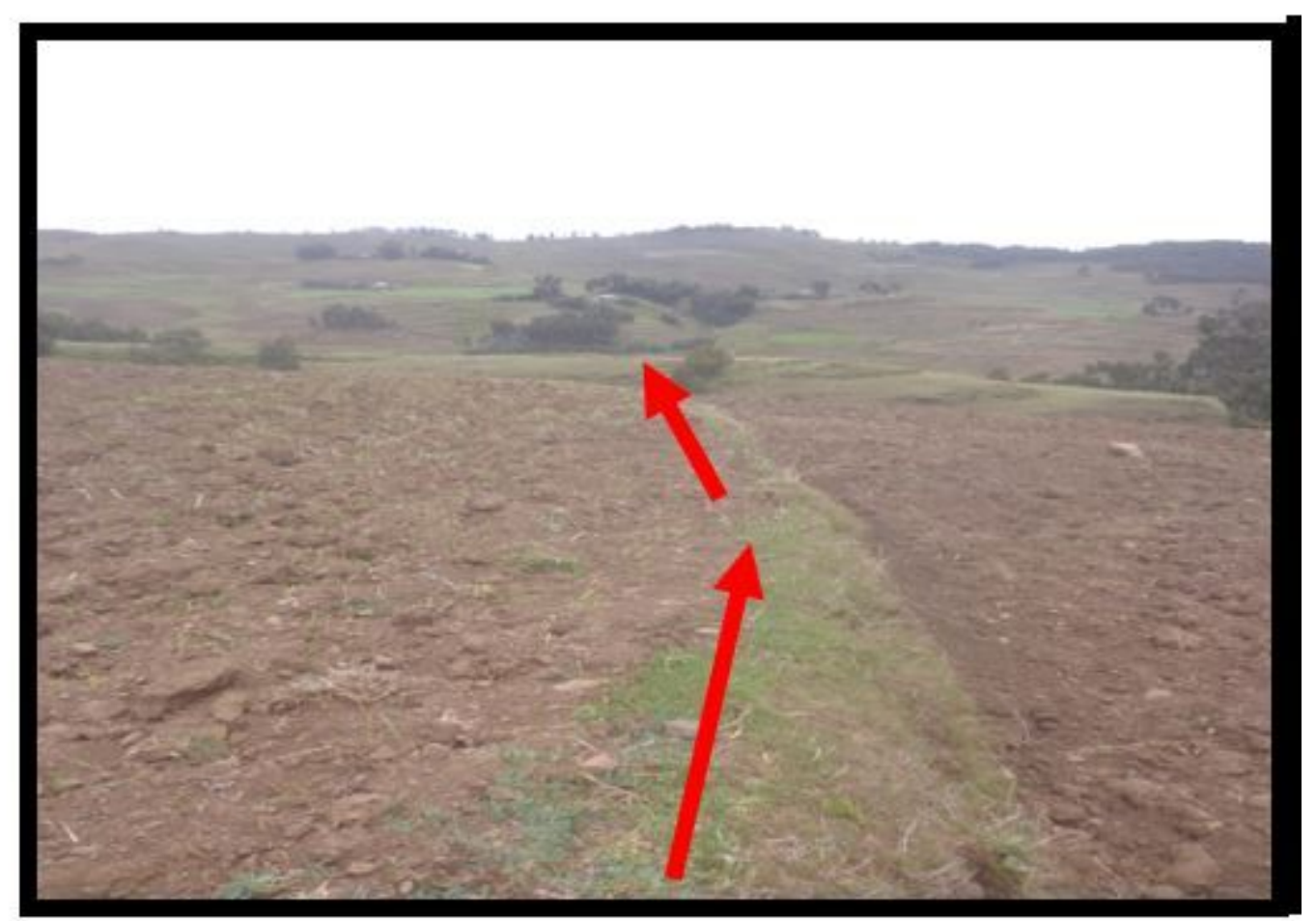

Figure 2

Up-graded soil bund in study area Source: Authors, 2019

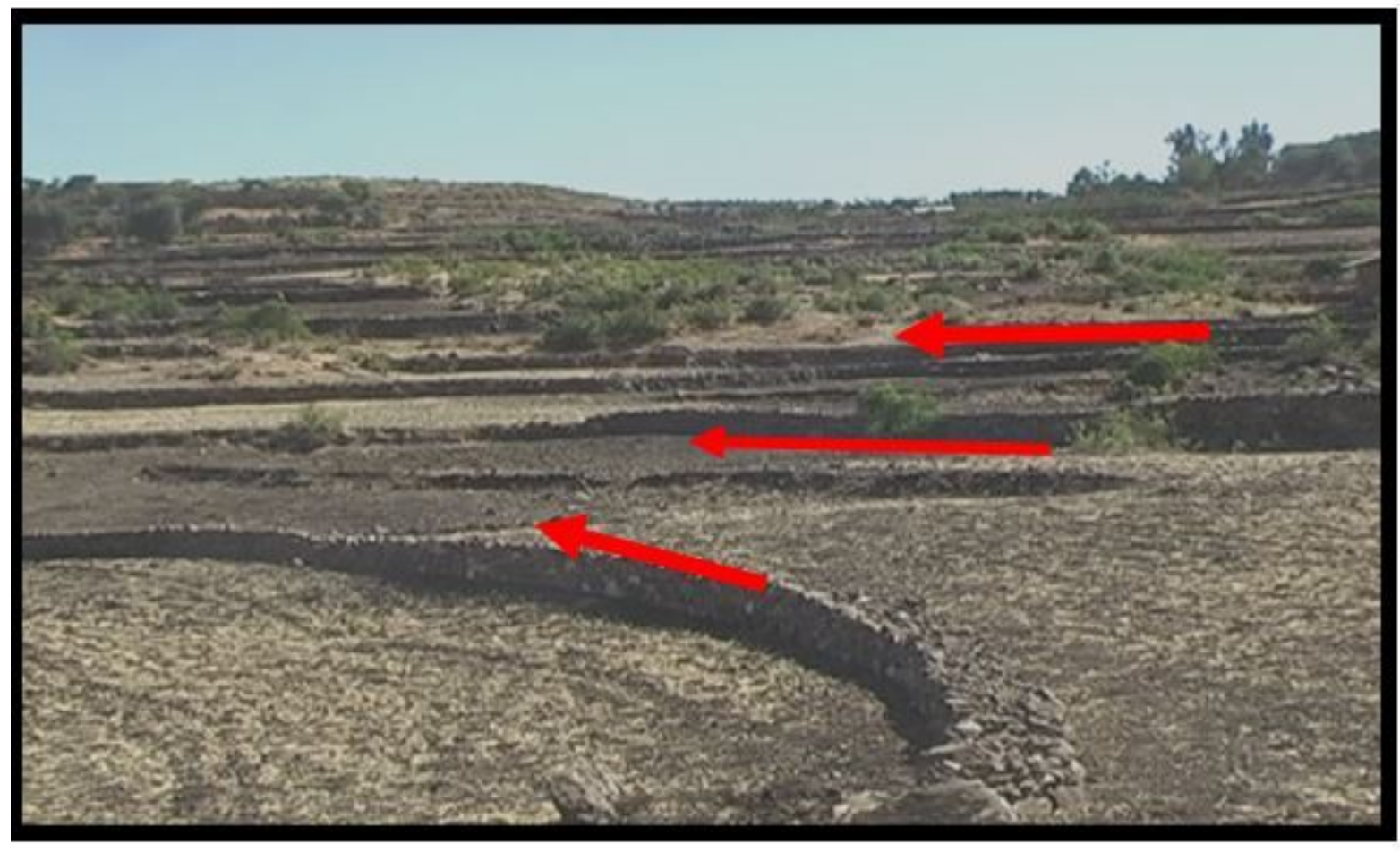

Figure 3

Stone bund in study area Source: Authors, 2019 


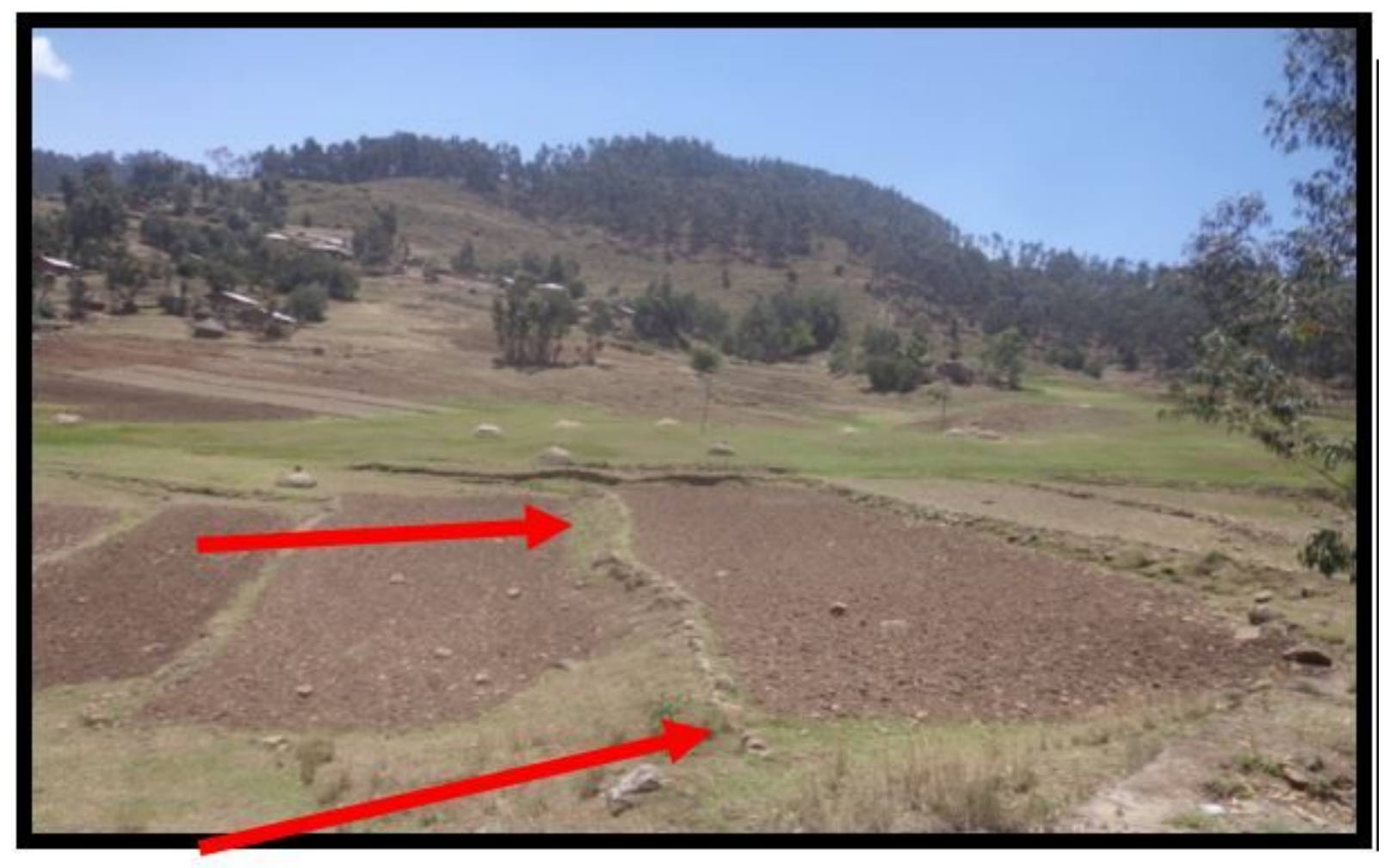

Figure 4

Stone -faced soil bund Source: Authors, 2019

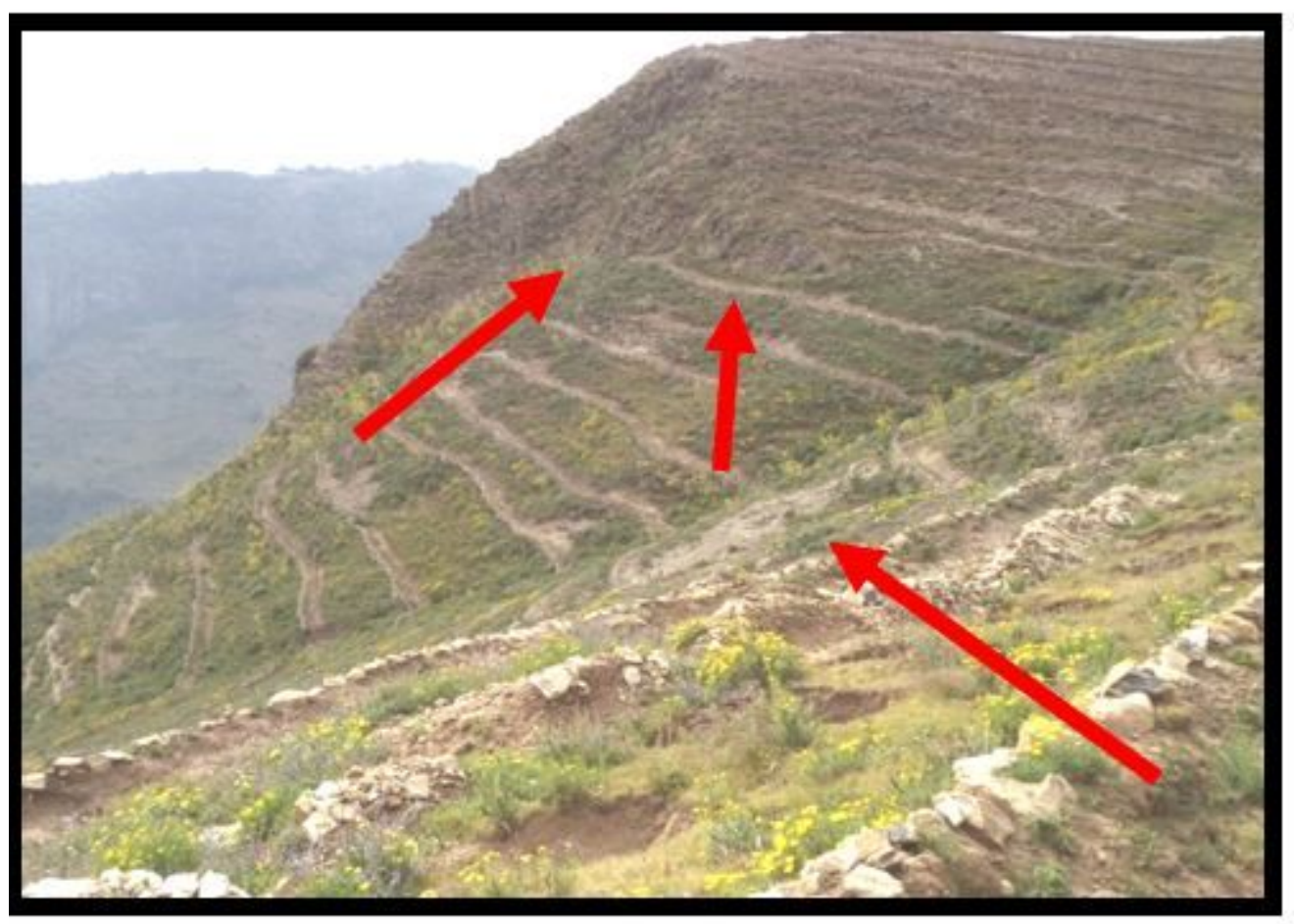

Figure 5

Hillside terraces 


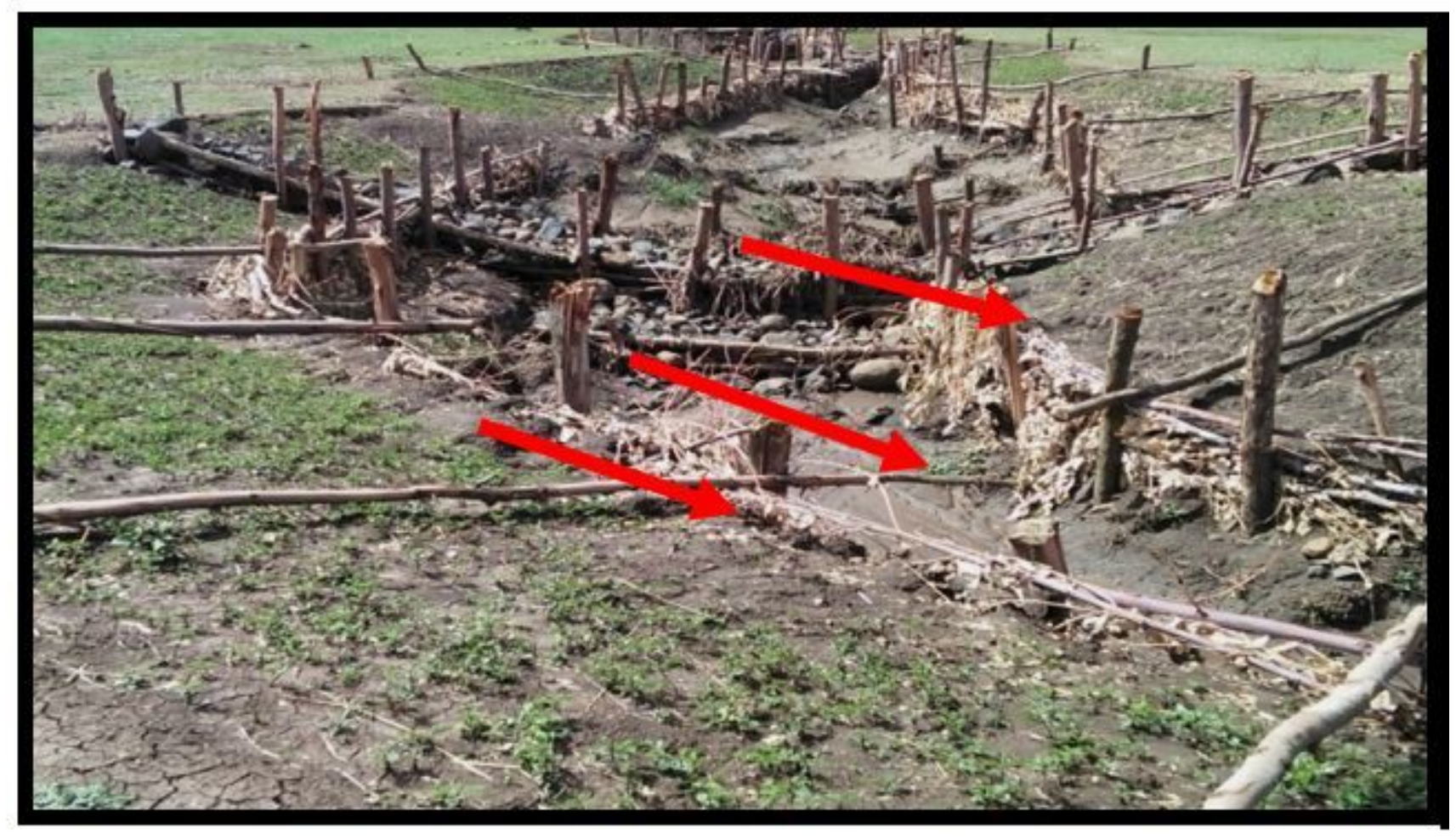

Figure 6

Brush wood check dam Source: Authors, 2009

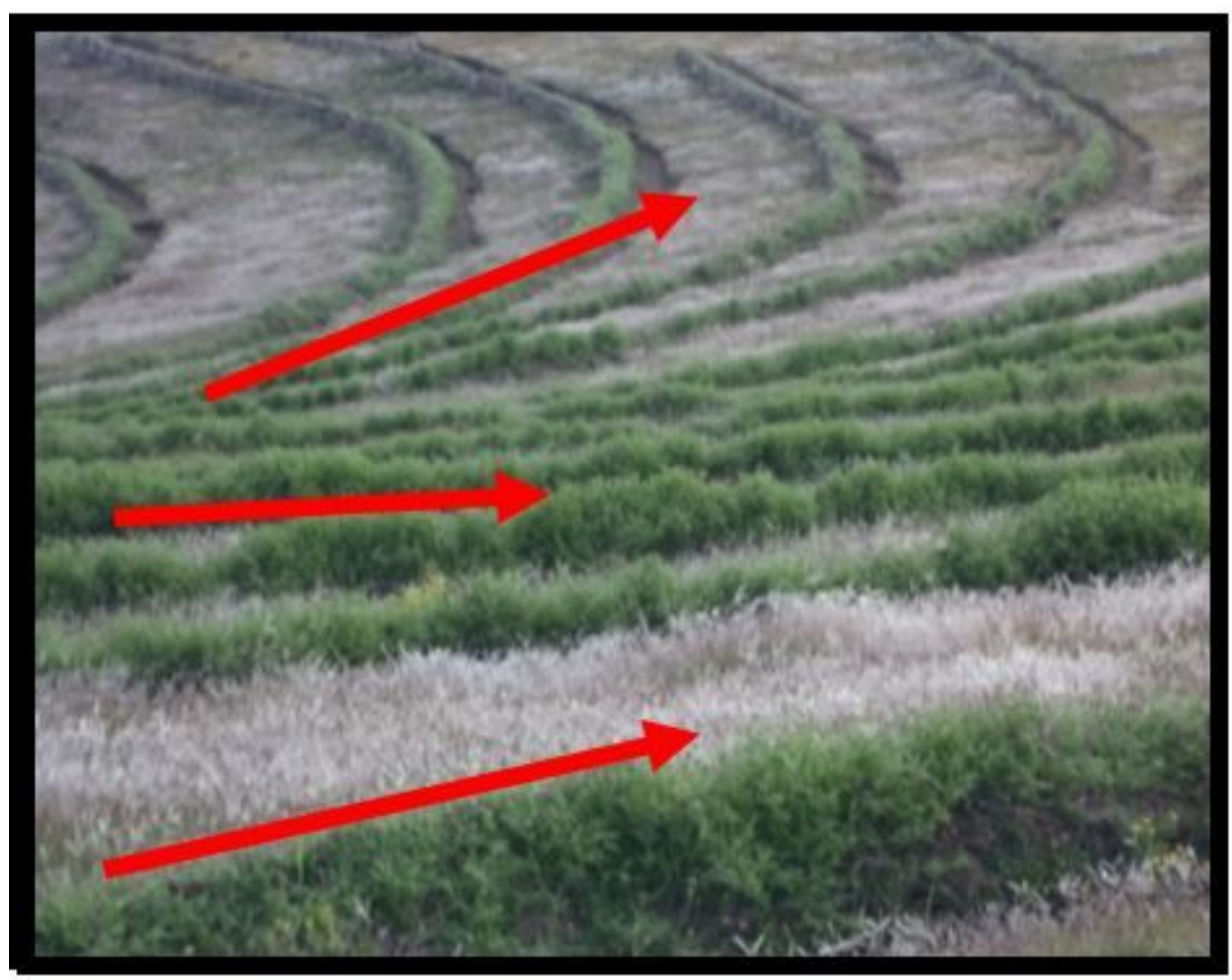

Figure 7 


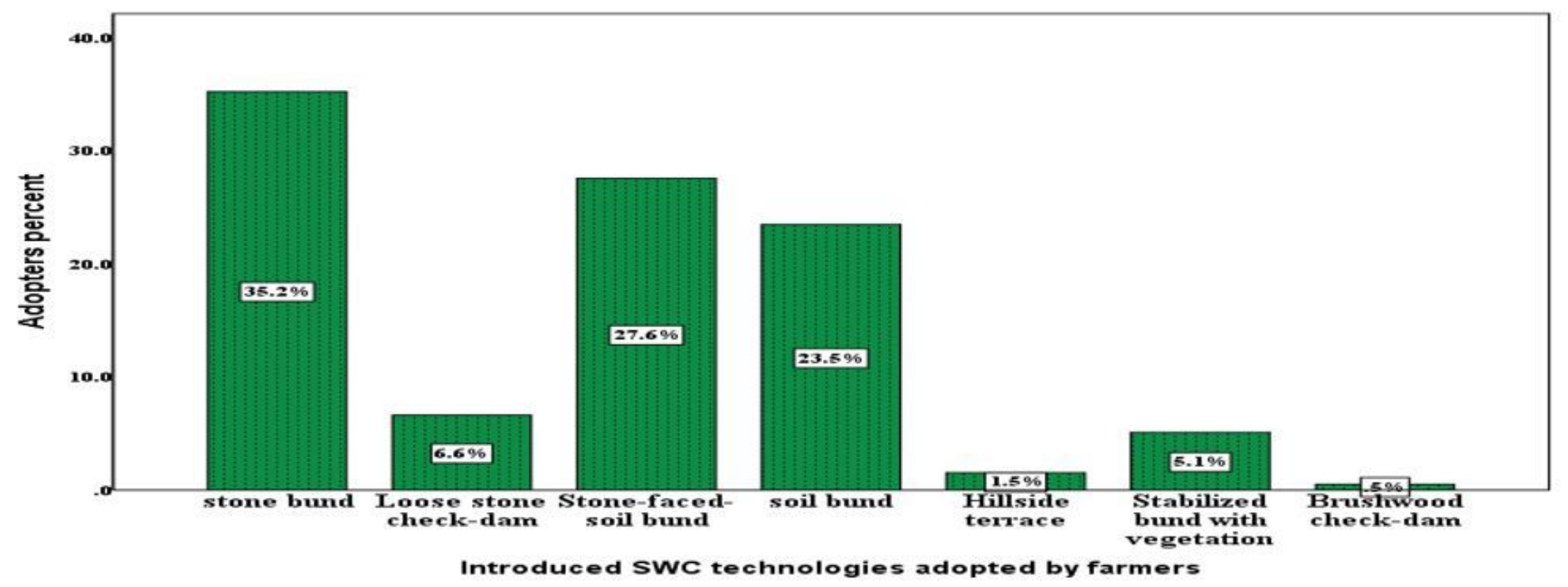

\section{Figure 8}

Soil and water conservation practices in Lege-lafto watershed Source: Field survey, 2019 